\title{
Should I stay, or should I go? self-legitimacy of attorneys in an authoritarian state
}

\author{
Yulia Khalikova $^{1}$ (D) - Anton Kazun ${ }^{2}$
}

Accepted: 15 December 2020/ Published online: 19 January 2021

(C) The Author(s) 2021

\begin{abstract}
In non-democracies, lawyers face various constraints ranging from the absence of acquittals or violations of their clients' rights to threats and criminal proceedings against them. Yet, we know little about the working conditions of attorneys' in authoritarian regimes, and what influences their desire to remain in the profession. Using a survey of attorneys in Russia, our study demonstrates which factors impact the desire to stay in the profession and how selflegitimacy influences these choices. We find that the frequency of violations of their clients' rights by law enforcement agencies undermines self-legitimacy of attorneys. In turn, this increases the attorneys' willingness to leave the profession, which is mitigated by two factors. First, attorneys with closer contacts with their colleagues in the regional bar associations are less willing to leave the bar for other career options. Second, when such associations actively exclude their members for violations of professional ethics, bona fide attorneys are more willing to stay. Lastly, we find that the expressed desire of leaving the profession transforms into actual voluntary leave in the following year. These findings have important implications, as attorneys do not only defend their clients but can also influence the political regime, either through the mobilisation of law or engaging into collective actions with their colleagues.
\end{abstract}

Yulia Khalikova

ykhalikova@bigsss-bremen.de

Anton Kazun

akazun@hse.ru

1 Bremen International Graduate School of Social Sciences, University of Bremen and Jacobs University Bremen, UNICOM-Building, Haus 9, Mary-Somerville-Str. 9, 28359 Bremen, Germany

2 International Centre for the Study of Institutions and Development, HSE University, Myasnitskaya Str. 18, 101000 Moscow, Russia 


\section{Introduction}

The profession of attorney is complex and requires high qualifications, which, in addition to high levels of performance and education, calls for adherence to strict standards of professional ethics [1-3]. Under a specific 'social contract' [4], attorneys strictly follow standards set by ethics codes in exchange for the trust of society which, in turn, provides attorneys with money and reputation. But what if the trust between society and attorneys is destroyed? What happens if attorneys stop considering their jobs as useful and legitimate?

This study advances our understanding of the impacts of political regime on legal professionals and especially their desire to stay in the profession. This topic is especially crucial for authoritarian regimes where the rule of law is not always respected and thus negatively impacts the attorneys' work. In the absence of independent courts [5], attorneys have to face the harsh realities of authoritarian governance when interacting with the judiciary and law enforcement agencies. In such settings, the defendants' rights are often violated throughout all stages of criminal proceedings [6-8], and what is typically considered a routine professional activity for lawyers can turn into a real war with the political regime.

In the meantime, we know very little of legal professionals in authoritarian states. What makes attorneys continue their work and what, on the contrary, forces them to leave their profession? It is especially important as attorneys can have an impact not only on their clients by representing them, but also on the (criminal) justice system in general and, in specific cases, on the political regime [9]. Attorneys routinely use the law in courts to challenge the state, but can also engage in collective actions with their colleagues [10]. Focusing on Russia and following literature on the self-legitimacy of professional groups, we analyse which factors influence the attorneys' (advokaty) departure from the legal profession in an imperfect law enforcement system. We base our analysis on a survey of attorneys in 35 regions of the country and on regional level data obtained from government agencies.

Russia is a good case for examining why attorneys want to leave their profession for two reasons. First of all, Russia belongs to a larger group of countries that can be classified as a competitive authoritarian regime [11]. These states have duality in governance where constitutional and administrative regimes co-exist in one paradigm $[12,13]$. Such duality is also pronounced in the legal sphere including courts and law enforcement agencies [14-16], where the system performs well for routine cases, but not for high-stakes or politically sensitive ones [17]. While being independent of the government, the community of attorneys operates within the existing system of cooperation between judges and law enforcement agencies [18]. Institutionally, this makes them the weakest professional group in the legal domain [19], but the only one that has to resist the obvious violations of the rule of law continuously.

Secondly, the law enforcement system in Russia is characterised by a high degree of heterogeneity $[20,21]$ due to high levels of socio-economic and political diversity among the regions [22-24]. For example, violations of the rights of defendants by judges or law enforcement officers such as prosecutors, investigators, or the police, might be frequent in one region of the country while non-existent in the others. This pronounced regional variation allows us to compare regions based on our variables of 
interest, namely the frequency of violations of defendants' rights by law enforcement agencies, and the frequency of attorneys' departures from the profession.

We begin by revisiting the literature on why attorneys leave their profession focusing on self-legitimacy, which is internal confidence in the moral validity of their professional power. Next, we provide background information on attorneys and the criminal justice system in Russia. Later sections describe our data, hypotheses, and methods. Firstly, we hypothesise that direct experience with violations of the rights of defendants undermines attorneys' self-legitimacy, which in turn increases their desire to leave the profession. Secondly, attorneys with stronger ties to their colleagues are more inclined to stay in the profession. Finally, the frequency of disbarment by the regional chamber of attorneys for violations of professional and ethical standards can decrease attorneys' readiness to change the profession. We test these hypotheses on a survey of attorneys and public data from the Ministry of Justice and the Russian Federal State Statistics Service using regression analysis. In the last section, we discuss the contribution of our results to an understanding of self-legitimacy of attorneys in this unfavourable institutional environment.

\section{Reasons for leaving the profession: Why focus on self-legitimacy?}

It is not easy to leave the profession of an attorney because it entails a large amount of time and resources invested in passing the bar. However, it does indeed occur regularly. Scholarship mostly describes this phenomenon in the context of job satisfaction [25]. The desire to leave the profession is connected to differences in the social background [26], high levels of dissatisfaction [27], the size of entry cohorts to the legal profession [28], and economic difficulties [29]. The organisational environment can both increase stress and reduce it, making relations with colleagues [30] and levels of involvement in the work of a law firm, such as the degree of professional duties in respondents' lives [31], very important. Other reasons for leaving the profession are the glass ceiling connected with gender inequality [28, 32-34] and the lack of flexibility for family commitments [27, 35, 36].

Apart from these reasons, many lawyers quit their practice voluntarily to pursue careers in other fields, such as academia, government or corporate affairs, which do not require them to be practicing bar members [37]. For example, in Russia, attorneys invest an additional four to five years of legal education, internship and the bar exam before receiving their status. However, lawyers without this status can still practice law in all areas except criminal law.

Another prominent part of the scholarship on job satisfaction and departure from the profession is research on self-legitimacy, which so far has mostly been applied to law enforcement officers or judges. Usually, it shows how an individual within a particular professional group is related to the group's activity, measured through survey questionnaires. For instance, self-legitimacy is measured via feelings of authority and knowledge to perform the job, and the right to exercise one's power [38, 39], as well as the importance of explaining their decisions to citizens [39]. More specifically, it transfers to the trust in the professionals' moral eligibility to exercise power [40], and the belief that the use of their professional skills, in some cases including force, is governed by professional rather than selfish goals. Such performance should also be 
supported by other members of the professional group and the public. Hence, the two most common factors used to measure self-legitimacy are public trust and a feeling of professional integrity, which shows how an individual perceives his or her colleagues to behave $[40,41]$.

What makes self-legitimacy important is that it is closely connected to the quality of professional services provided by members of the group. When the feeling of selflegitimacy is lost, professionals cannot fully fulfil their duties [42]. In the context of prisons, for example, high levels of self-legitimacy influence the efficiency and professionalism of correctional officers that in turn positively affects the implementation of tasks in prison, guards' relations with prisoners, and the maintenance of order [38]. Taking the example of police officers, Nix and Wolfe [43] show that negative coverage of the police in the media influences public perceptions of the police and thus undermines self-legitimacy of police officers. Following that, Noppe [44] shows that police officers with lower levels of self-legitimacy use force more often compared to officers with higher levels of self-legitimacy.

Although self-legitimacy is essential for law enforcement officers who must be prepared to use weapons in certain circumstances [45], we argue that the same conclusions can be applied to attorneys. Indeed, without the belief that their work is valuable and necessary, especially in repressive and often unfair trials, attorneys cannot fulfil their duties of representing clients and protecting them from the flawed justice system.

As a consequence, constraints imposed by the authoritarian political regime, most visibly violations of the rights of attorneys and their clients throughout various stages of criminal justice proceedings can and do impact attorneys' self-legitimacy and, in turn, their desire to change the profession. However, there is little empirical research on possible connections between such violations by judges or law enforcement officers and attorneys' departures from the profession, since most scholarship on the legal profession is conducted in democracies. Only a few studies [46, 47] are directly focused on attorneys' struggles of maintaining independence from law enforcement in authoritarian countries. Nevertheless, it is important to understand why attorneys stay in their profession under such circumstances, especially when their collective actions can contribute to the democratisation and the development of the rule of law $[48,49]$.

\section{Background: Legal profession in Russia and attorneys}

In Russia, there is no monopoly of advocates, and two groups can represent clients' interests in courts - advokaty (in the future we will call them attorneys) and other legal professionals (iuristy). To litigate a criminal case, one must be qualified as an attorney, whereas for non-criminal cases the only requirement is to be a mentally competent adult (see [50]).

In this paper, we focus only on attorneys due to the following reasons. Attorneys in Russia constitute a particular professional group with high entry costs. To become an attorney, one has to hold a diploma in law with more than two years of professional postgraduate experience and pass a bar exam. Hence, having attorney status means that an individual has invested a certain amount of time and resources into obtaining it. 
Since only attorneys can represent clients in criminal cases, they are the only part of the legal community that deals with the repressive governmental system daily. Legal professionals handling only non-criminal cases have different problems and do not have to enter into confrontation with law enforcement officers or judges. However, the focus of this paper on attorneys does not imply that our study analyses the experiences of those professionals who handle criminal cases only. On average, Russian attorneys handle 56 cases a year, 27 out of which are non-criminal.

As studies of attorneys show [51], their community is very heterogeneous in terms of work experience and professional ethics. Thus, the same status unites both relatively honest attorneys and those who focus mainly on personal gains and are ready to partake in corrupt deals. As a consequence, the same professional status unites a wide range of professionals.

Additionally, we focus on the role of professional self-regulatory associations. Each attorney is a member of one of the Regional Chambers of Attorneys (RCA). The Ministry of Justice regularly collects statistics on them, allowing us to access the data needed for our research. For non-attorneys, there is no requirement of qualification or registration, and thus no reliable data on them is available $[52,53]$. On the contrary, the work of attorneys is regulated by two main acts - the 2002 Federal Law No 63 'On Legal Practice and Advocacy in the Russian Federation' (Federal Law) and the 2003 Code of Attorneys' Professional Ethics (the Code).

Regional chambers are self-regulatory institutions, and their leadership is elected directly by the chamber members. Among other tasks, RCAs have jurisdiction over disbarment procedures connected to various reasons, including violations of the Code. Among possible disciplinary sanctions are reprimand, warning, or disbarment (art. 18 of the Code). Russian regions differ in socio-economic development and the conditions that lawyers have to operate within. Whereas some regional chambers of attorneys strictly monitor compliance with professional ethics and punish violators, others are significantly less strict. This variation allows dishonest or underqualified lawyers to enter the profession in the first place and later stay in it, when a chamber does not strictly control the quality of its members' work.

Thus, focusing on attorneys is justified for the following reasons. They comprise a distinct and clearly defined professional group united by their shared status, but still maintaining differences due to regional specifics, education, personal background and other factors. Additionally, we can access unique data on attorneys, since each one has to be a member of the RCA. Following up, the RCAs monitor the activity of attorneys, at least in terms of ethical proceedings and disbarment procedures. Given the additional focus of our paper on the role of (regional) professional organisations, we can test whether more frequent communication with the RCA and colleagues from the region impact attorneys' self-legitimacy and, in turn, their desire to leave (or stay in) the profession.

\section{The criminal justice system in Russia: A threat to attorneys' self-legitimacy?}

In 2017, the rate of acquittals in criminal cases heard in Russian courts was $0.3 \%$ [54]. Such a low level of non-guilty verdicts is also known as the 'accusatory bias' $[55,56]$ and is common among many countries of the former Soviet Union [57]. When it comes to Russia, the acquittal rate is continuously decreasing. The reason behind this is a 
performance evaluation system that considers any not guilty verdict as evidence of the low quality of law enforcement work. Detailed analysis of this phenomenon is outside of the scope of this paper (see $[18,58]$ ), but we will focus on several significant consequences of such a system.

First, the absence of acquittals can be achieved only through regular violations of the rights of defendants $[59,60]$. If there is even a slight chance of acquittal, the law enforcers will opt to close criminal investigation before the trial phase. If it has already made it to trial, then a defendant has virtually no chances of getting an acquittal. When there is not enough evidence, law enforcement officers can resort to intimidation, violence or falsification of evidence.

Second, such a system inflicts severe damage to the reputation of an attorney, who is, to some extent, helpless in these circumstances. According to recent studies $[19,55]$, in a system where the accusatory bias prevails, attorneys can expect only some mitigation of judgement, such as a suspended sentence or lower sentence duration. Following these arguments, it is expected that throughout their careers, attorneys will have only a few not guilty verdicts. According to our survey, only $31 \%$ of Russian attorneys with more than 15 years of experience have never received a non-guilty verdict. Given this, society does not see attorneys as professionals who can help them to counter the criminal justice system. Similarly to China [46], law enforcement officers do not consider attorneys as full and equal partners in the justice system.

In this framework, the primary professional activities of attorneys are considered by law enforcement agencies as a direct threat to their careers. Titaev and Shkliaruk [61] describe that an unexpected acquittal means punishment ranging from depriving of bonuses to possible dismissals for other actors in the criminal justice system. As a consequence, not only defendants' but also attorneys' rights can be violated by law enforcement. For example, Kazun and Yakovlev [10] demonstrate that law enforcement officers initiate criminal cases against lawyers.

To summarise, the existing system in Russia indeed impacts the work of attorneys. Being the only professional group that can litigate criminal cases, attorneys face harsh realities of the criminal justice system daily. In doing so, they have to resist the pressure from judges and law enforcement agencies who often resort to procedural and physical violations of the rights of defendants to achieve guilty verdicts. In the absence of notguilty verdicts, both society and members of other legal communities do not consider attorneys' work as important. This can negatively impact self-legitimacy of attorneys, and increase their desire to pursue different career paths. Despite that, even in the circumstances more extreme than in modern Russia, there are still some individuals who continue to work under authoritarian regimes. This part is outside the scope of this paper, but more insights come from a diary of a human rights' advocate in the USSR [62], research on lawyers in China [63] or LGBT rights in Singapore [64].

\section{Hypotheses, data, and methods}

\section{Data}

Our research design combines individual-level and group-level (based on the regions of Russia) data. For individual level, we use data from a survey of Russian attorneys 
conducted in 2014 with the support of the Russian Federal Bar Association. The survey includes responses of 3317 attorneys from 35 out of 85 regions in Russia (see Tables 1 , 2 and 3 for more details). As each attorney in Russia is registered by one of the Regional Chamber of Attorneys, access to them was provided by the RCAs who distributed printed questionnaires. The response rate was about 20-25\%, which coincides with similar studies conducted in the US context [65].

Our sample corresponds to the general population of attorneys by gender and age, but contains biases regarding regional representation and professional organisation (Table 3). To overcome this, we have weighted our survey data by the region of the respondent. Additionally, we control for the type of legal organisation each respondent works at. ${ }^{1}$ We also use the answers about the perceived level of income in the region to control for the financial conditions of an attorney's work. For regional-level, we use publicly available data on regional population, the total number of attorneys and disbarment numbers retrieved from the websites of the Ministry of Justice of the Russian Federation and the Federal State Statistics Centre.

\section{Hypotheses and operationalisation of variables}

Research on self-legitimacy has mostly been focused on police and prison officers. Still, we argue that these findings can also be applied to attorneys, who constitute a close professional group with a self-governing mechanism. Additionally, we know little about self-legitimacy in countries with authoritarian rule and what makes attorneys continue their work in such conditions. We provide an operationalisation of our variables in Table 4.

To begin with, we construct self-legitimacy on two levels. The first is public trust [40], which we measure using a survey question about attorneys' perceived feelings of mistrust towards lawyers from the general population (mistrust). The second deals with the perceived integrity of other members of the professional group. It can be measured using the perceived sense of moral standing among other members of the profession [38], self-discipline [66], belief that decisions are taken fairly and honestly [42, 66], and audience legitimacy [67]. In our study, we use the survey's question measuring the general belief that the legal profession is an example of an honest and ethical one to measure perceived integrity (honesty).

Attorneys in Russia face frequent procedural violations and very few non-guilty verdicts. Such conditions could negatively impact their self-legitimacy. To account for this, we use a survey question of how often in the last three years each respondent have encountered violations of their clients' rights by judges and law enforcement, including prosecutors, investigators, police and prison officers. We create an index for each respondent (violations of rights index) by grouping responses to these six sub-questions and calculating the mean for each respondent. We thus formulate the following hypothesis:

- $H_{1}$. Frequent violations of the rights of defendants by judges and law-enforcement undermine the professional self-legitimacy of attorneys.

\footnotetext{
${ }^{1}$ The Law on Attorneys and Advocacy envisages four main forms of practicing: bureaus of attorneys, attorneys offices, colleges of attorneys, and legal consultancy offices. The last two unite dozens of attorneys, while the first two are usually organised by experienced attorneys with their own clients' base.
} 
Table 1 Description of regions in the sample, numbers of attorneys in each region and in our sample, and calculated weights to use in the analysis

\begin{tabular}{|c|c|c|c|c|c|}
\hline $\mathrm{N}$ & region & abbreviation & \# attorneys & \# (sample) & weights \\
\hline 1 & Stavropolskii krai & STAVR & 1618 & 372 & 0.206 \\
\hline 2 & Respublika Tatarstan & TAT & 1243 & 337 & 0.174 \\
\hline 3 & Samarskaya oblast & SAM & 1670 & 281 & 0.280 \\
\hline 4 & Moskva (gorod) & MSK & 8963 & 275 & 1.538 \\
\hline 5 & Kurganskaya oblast' & JUR & 332 & 214 & 0.073 \\
\hline 6 & Krasnoyarskii krai & KRSNYRSK & 983 & 197 & 0.237 \\
\hline 7 & Nizhegorodskaya oblast' & $\mathrm{NZH}$ & 1201 & 184 & 0.311 \\
\hline 8 & Chelyabinskaya oblast' & $\mathrm{CHE}$ & 1094 & 101 & 0.519 \\
\hline 9 & Leningradskaya oblast' & LO & 1046 & 97 & 0.514 \\
\hline 10 & Vologodskaya oblast' & VLGD & 438 & 94 & 0.223 \\
\hline 11 & Ul'yanovskaya oblast' & ULYAN & 483 & 92 & 0.246 \\
\hline 12 & Kirovskaya oblast' & KIR & 398 & 79 & 0.236 \\
\hline 13 & Tumenskaya oblast' & TYUM & 752 & 59 & 0.595 \\
\hline 14 & Ivanovskaya oblast' & IVAN & 357 & 54 & 0.318 \\
\hline 15 & Respublika Mordoviya & MOR & 286 & 52 & 0.255 \\
\hline 16 & Kaliningradskaya oblast' & KLNG & 567 & 50 & 0.538 \\
\hline 17 & Astrakhanskaya oblast' & ASTR & 541 & 49 & 0.514 \\
\hline 18 & Omskaya oblast' & OMSK & 640 & 48 & 0.651 \\
\hline 19 & Respublika Adygeya & $\mathrm{ADYG}$ & 304 & 45 & 0.309 \\
\hline 20 & Respublika Chuvashiya & CHUV & 329 & 45 & 0.335 \\
\hline 21 & Krasnodarskii krai & KRSNDR & 3674 & 44 & 4.024 \\
\hline 22 & Respublika Marii-El & MARI & 230 & 43 & 0.252 \\
\hline 23 & Moskovskaya oblast' & MO & 5323 & 42 & 5.830 \\
\hline 24 & Respublika Kareliya & KAR & 230 & 42 & 0.252 \\
\hline 25 & Khanty-Mansiiskii krai & KHNT-MNS & 564 & 42 & 0.618 \\
\hline 26 & Novosibirskaya oblast' & NSK & 1121 & 41 & 1.330 \\
\hline 27 & Permskii krai & PERM & 1005 & 41 & 1.192 \\
\hline 28 & Ryzan'skaya oblast' & RYAZ & 493 & 41 & 0.585 \\
\hline 29 & Yaroslavskaya oblast' & YRSLV & 511 & 40 & 0.606 \\
\hline 30 & Kemerovskaya oblast' & KEM & 787 & 39 & 0.934 \\
\hline 31 & Tverskaya oblast' & TVE & 452 & 39 & 0.536 \\
\hline 32 & Respublika Udmurtiya & UDM & 638 & 38 & 0.826 \\
\hline 33 & Sverdlovskaya oblast' & SVE & 1927 & 35 & 2.494 \\
\hline 34 & Respublika Buryatiya & BUR & 424 & 32 & 0.604 \\
\hline 35 & Khabarovskii krai & КНАB & 616 & 32 & 0.877 \\
\hline
\end{tabular}

Feelings of mistrust towards the legal profession from the population and dishonesty within the legal community itself make it harder for attorneys to fulfil their duties and may contribute towards their desire to leave the profession. We have already touched upon other factors, such as dissatisfaction with salary or work-life balance, as well as 
Table 2 Operationalisation of variables

\begin{tabular}{|c|c|}
\hline Variable & Operationalisation \\
\hline \multicolumn{2}{|l|}{ Dependent variables } \\
\hline Honesty & $\begin{array}{l}\text { 'The profession of a lawyer in Russia is an } \\
\text { example of honest, } \\
\text { law-abiding and ethical conduct' }\end{array}$ \\
\hline Mistrust & $\begin{array}{l}\text { 'Russians who have no legal education often } \\
\text { mistrust lawyers' }\end{array}$ \\
\hline Readiness to quit & $\begin{array}{l}\text { 'I am prepared to leave the profession if I find a } \\
\text { job with a higher } \\
\text { salary but not in the legal field' }\end{array}$ \\
\hline Left voluntarily & $\begin{array}{l}\text { Attorneys who revoked their license voluntarily to } \\
\text { the total number } \\
\text { of attorneys leaving the bar in the same region } \\
\text { (2015) }\end{array}$ \\
\hline
\end{tabular}

\section{Independent variables}

Violations of rights

Individual-level index constructed using responses to the question:

'How often in your region for the last three years have you encountered violations of your clients' rights by: judges, prosecutors, investigators from the Investigative Committee, investigators from the Ministry of Internal Affairs, other representatives of the MIA, members of the Federal Penitentiary Service'.

Bar ties

Individual-level index constructed using responses to the question:

Responses

- absolutely disagree; 1 rather disagree; 2 absolutely agree; 3 rather agree

Responses to these sub-questions were grouped together for each respondent and calculated to get a mean.

'How often in the last year have you taken part in various professional events held by the Regional Chamber of Attorneys?', with five sub-questions identifying types of activities (conferences, workshops on legal topics, cultural and sport events, informal meetings, professional holidays)

Type of legal organization Dummy variables for four types of legal organisations, where respondents are basing their work at (college of attorneys, bureau of attorneys, attorney's office, and legal consultancy)

\section{Control variables}

\section{Age}

Gender: female

Education: legal

Type of first university degree received

0 - not law school;

1 - law school

Bar experience

Number of years a respondent has worked as an attorney

Perceived income

Log of perceived income in the region for (1) experienced attorneys; and (2) early-career attorneys

Responses were groups to calculate the mean 
Table 2 (continued)

\begin{tabular}{|c|c|c|}
\hline Variable & Operationalisation & Responses \\
\hline Demand (regional) & $\begin{array}{l}\text { 'In your opinion, how has the demand for legal } \\
\text { services in your region } \\
\text { changed over the last five years?' }\end{array}$ & \\
\hline \multicolumn{3}{|l|}{ Regional level } \\
\hline Readiness to quit (2014) & $\begin{array}{l}\text { Regional level variable calculated using responses } \\
\text { to 'readiness to quit' question }\end{array}$ & \\
\hline \# attorneys & $\begin{array}{l}\text { Number of attorneys registered in the region at the } \\
\text { end of the reporting year }(2014)\end{array}$ & \\
\hline Attorneys per capita & $\begin{array}{l}\text { The ratio of attorneys to population of a region } \\
\text { (per capita) }\end{array}$ & \\
\hline \# attorneys disbarred & Number of attorneys disbarred (2014) & \\
\hline $\begin{array}{l}\text { \# attorneys disbarred due } \\
\text { to ethical violations }\end{array}$ & $\begin{array}{l}\text { Number of attorneys disbarred due to violations of } \\
\text { ethical conduct (2014) }\end{array}$ & \\
\hline Unethics2out & $\begin{array}{l}\text { The ratio of a number of attorneys disbarred due } \\
\text { to violations of ethics to } \\
\text { the total number of attorneys disbarred by the } \\
\text { RCA in } 2014\end{array}$ & \\
\hline
\end{tabular}

the desire to pursue a career in other directions, which significantly affect the desire to leave the legal profession. However, these factors might be of lesser importance in autocracies. We believe that due to constant communication with the judicial and law enforcement systems, attorneys in non-democracies are more dependent on their selflegitimacy, which might increase their desire to leave the profession.

We test this assumption using a survey question that asks the respondent's readiness to leave the profession if they were to find a job with a higher salary, but outside of the legal field (readiness to quit). However, the job is not limited to earning money only, but entails a system of values and responsibility before the public. Leaving the profession for another job indicates that professional values are not that important, after all. Following this line of argument, we expect that:

\section{- $\mathrm{H}_{2}$. Attorneys with low levels of self-legitimacy are more inclined to leave the profession.}

In line with the existing scholarship, we assume that the organisational environment and professional associations play an important role. When professional socialisation is either weak or absent, attorneys who do not have a strong professional network have to rely on themselves in decision-making [68] or follow the behaviour observed among other attorneys [69].

As a proxy for the influence of the organisational environment, we create an individual level index measuring the extent of connections to their regional chamber of attorneys (bar ties index). For this, we use a survey question on the frequency of attending professional events, including conferences, research workshops, cultural or sports events, informal meetings, and professional holidays. Following that, we assume that the organisational environment influences attorneys' self-legitimacy and thus their desire to change their profession, leading to the following hypothesis: 
Table 3 Summary statistics for variables used in main analysis (weighted and imputed data)

\begin{tabular}{|c|c|c|c|c|c|}
\hline Statistic & $\mathrm{N}$ & Mean & St. Dev. & Min & Max \\
\hline \multicolumn{6}{|l|}{ Dependent variables } \\
\hline Honesty & 3317 & 0.696 & 0.460 & 0 & 1 \\
\hline Mistrust & 3317 & 0.480 & 0.500 & 0 & 1 \\
\hline Readiness to quit & 3317 & 0.260 & 0.439 & 0 & 1 \\
\hline Left voluntarily (2015) & 35 & 0.665 & 0.139 & 0.316 & 0.911 \\
\hline \multicolumn{6}{|l|}{ Independent variables } \\
\hline Year born & 3317 & 1970 & 11.353 & 1928 & 1995 \\
\hline Gender: female & 3317 & 0.435 & 0.496 & 0 & 1 \\
\hline Education: legal & 3317 & 0.217 & 0.412 & 0 & 1 \\
\hline Years of working as an attorney & 3317 & 10.913 & 8.948 & -1 & 58 \\
\hline Age & 3137 & 43.553 & 11.364 & 19 & 86 \\
\hline Perceived demand for lawyers & 3317 & -0.191 & 0.774 & -1 & 1 \\
\hline Bar ties (index) & 3317 & 1.137 & 0.860 & 0.000 & 3.000 \\
\hline Violations of rights (index) & 3317 & 1.604 & 0.808 & 0 & 3 \\
\hline \multicolumn{6}{|l|}{ Perceived violations by: } \\
\hline Judges & 3317 & 1.307 & 0.998 & 0 & 3 \\
\hline Prosecutors & 3317 & 1.427 & 1.025 & 0 & 3 \\
\hline Investigative Committee & 3317 & 1.681 & 1.002 & 0 & 3 \\
\hline Investigators, Ministry of Internal Affairs & 3317 & 1.855 & 0.958 & 0 & 3 \\
\hline Other officers at MIA & 3317 & 1.910 & 1.005 & 0 & 3 \\
\hline Federal Penitentiary Service & 3317 & 1.443 & 1.080 & 0 & 3 \\
\hline \multicolumn{6}{|l|}{ Participates in regional bar associations' events: } \\
\hline Assemblies and conferences & 3317 & 0.804 & 1.110 & 0 & 3 \\
\hline Research workshops & 3317 & 0.955 & 1.193 & 0 & 3 \\
\hline Culture and sport & 3317 & 0.635 & 1.061 & 0 & 3 \\
\hline Informal meetings & 3317 & 1.950 & 1.217 & 0 & 3 \\
\hline Professional holidays & 3317 & 1.344 & 1.217 & 0 & 3 \\
\hline \multicolumn{6}{|l|}{ Type of legal organisation: } \\
\hline College of attorneys & 3317 & 0.729 & 0.445 & 0 & 1 \\
\hline Bureau of attorneys & 3317 & 0.028 & 0.165 & 0 & 1 \\
\hline Attorney’s office & 3317 & 0.197 & 0.398 & 0 & 1 \\
\hline Legal consultancy & 3317 & 0.059 & 0.235 & 0 & 1 \\
\hline \multicolumn{6}{|l|}{ Perceived income in the region (log): } \\
\hline For experienced attorneys & 3317 & 11.040 & 0.881 & 0.693 & 16.118 \\
\hline For early-career attorneys & 3317 & 9.796 & 0.757 & 6.908 & 13.816 \\
\hline \multicolumn{6}{|l|}{ Regional level: } \\
\hline \# attorneys in the region (2014) & 35 & 1734.252 & 2366.4 & 231 & 9137 \\
\hline \# attorney disbarred (2014) & 35 & 46.468 & 40.220 & 2 & 150 \\
\hline $\begin{array}{l}\text { \# attorneys disbarred for violations of ethical code } \\
\text { (2014) }\end{array}$ & 35 & 5.255 & 6.000 & 0 & 21 \\
\hline $\begin{array}{l}\text { Ratio of disbarred for violations of ethics to all } \\
\text { disbarred (2014) }\end{array}$ & 35 & 0.127 & 0.084 & 0.000 & 0.300 \\
\hline
\end{tabular}


Table 3 (continued)

\begin{tabular}{lccccc}
\hline Statistic & N & Mean & St. Dev. & Min & Max \\
\hline Population (2014) & 35 & $3,264,453$ & $2,982,603$ & 45,326 & $12,263,861$ \\
Ratio of attorneys to population per capita & 35 & 0.530 & 0.738 & 0.220 & 6.707 \\
\# attorneys disbarred (2015) & 35 & 51.302 & 50.398 & 5 & 197 \\
\# attorneys leaving voluntarily (2015) & 35 & 31.473 & 23.404 & 2 & 82 \\
Ration of leaving voluntarily to disbarred (2015) & 35 & 0.665 & 0.139 & 0.316 & 0.911 \\
\hline
\end{tabular}

- $H_{3}$. Attorneys with closer and more frequent interaction with colleagues have higher levels of self-legitimacy and are less prone to leave the profession.

Given regional differences, we also want to test the influence of regional variation in disbarment practices on readiness to leave the profession. Here, we assume that by excluding members who violate ethical standards, a professional organisation can sustain the desired levels of quality within the professional group. Disbarment improves the quality of services provided by the group and thus the attorneys' self-legitimacy who believe they are surrounded by honest colleagues [70]. Moreover, the failure of professional organisations to punish unethical misconduct provides a bad example to other members of the group and lowers the quality of services [71, 72].

Thus, we assume that reasonable levels of controlling the quality of the legal profession can benefit the professional community and lower the outflow of professionals. To measure this, we construct a variable measuring the proportion of attorneys being disbarred for violations of professional and ethical conduct (unethics2out). For these purposes, we consider an attorney to be disbarred for unethical behaviour if they were disbarred due to one of the following events (art 17 of the Federal Law N 63): 1) inadequate performance of professional duties; 2) violation of the Code of professional ethics; 3 ) non- or unsatisfactory performance of the Chamber of Attorneys' rulings. ${ }^{2}$ Among the lawyers deprived of the attorney status (on average 46 in each chamber per year), $12.7 \%$ are disbarred for violations of professional and ethical conduct. However, the proportion of attorneys being disbarred for violations of professional and ethical conduct (unethics2out) varies from 0 to $30 \%$ in different regions. Hence, the hypothesis is as follows:

- $H_{4}$. There will be a lower desire to leave the profession in regions where attorneys are disbarred due to violations of professional ethics more frequently than for other reasons.

Last but not least, we want to test whether the expressed attitudes about the possibility of leaving the profession transform into real acts of departures from the law. In the absence of longitudinal data, we can test this hypothesis only indirectly. We match survey responses about readiness to leave their profession for better-paid jobs outside of the law with regional statistics on the number of attorneys who voluntarily revoked their status in the year following the survey (left voluntarily) (2015). Here, we expect that:

\footnotetext{
${ }^{2}$ Other reasons, which we considered to be not of ethical nature, are the following: submitting incorrect or false personal information to the Chamber before sitting for an exam; failure to inform the RCA of a chosen legal form of professional activity within 4 months after passing the bar.
} 


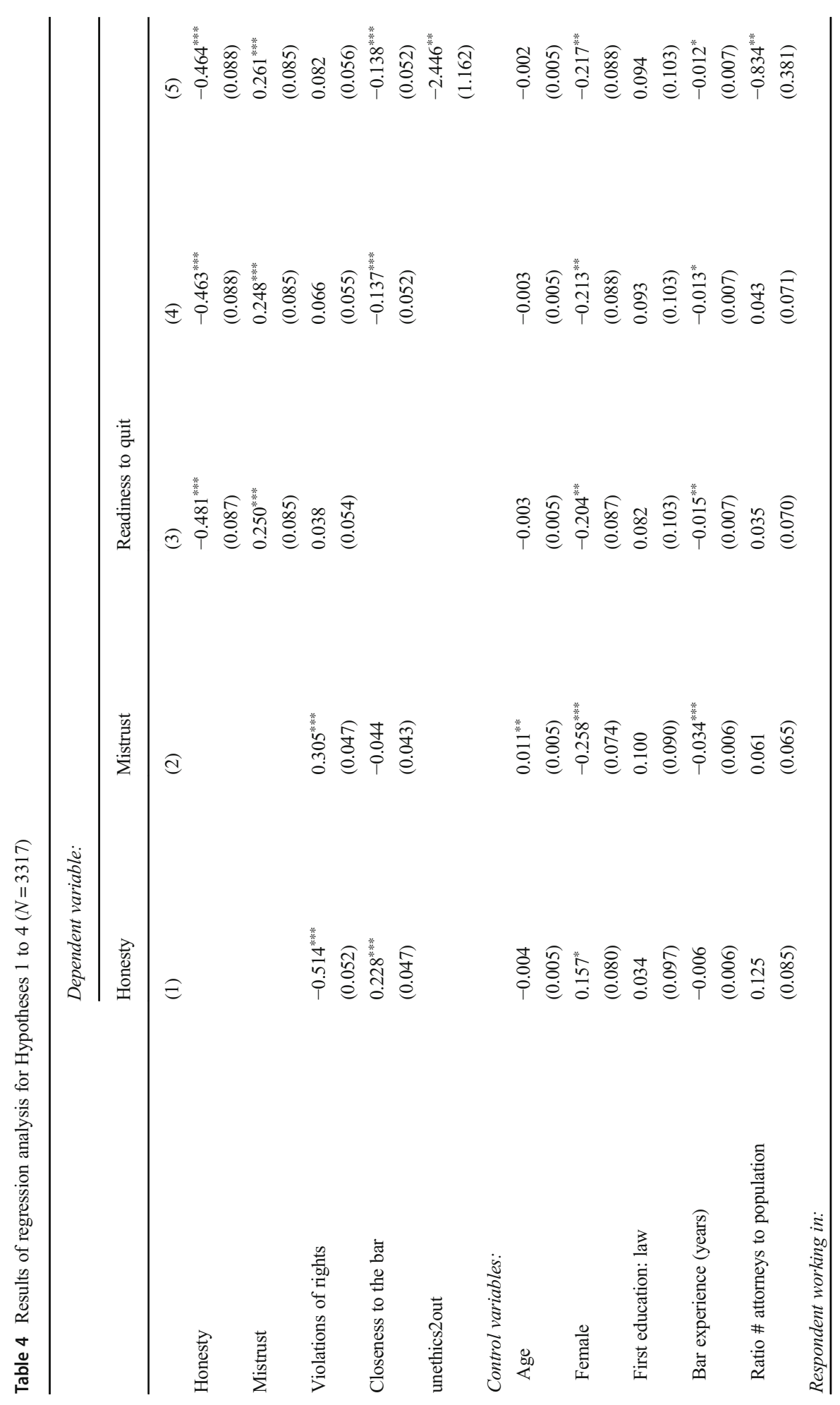




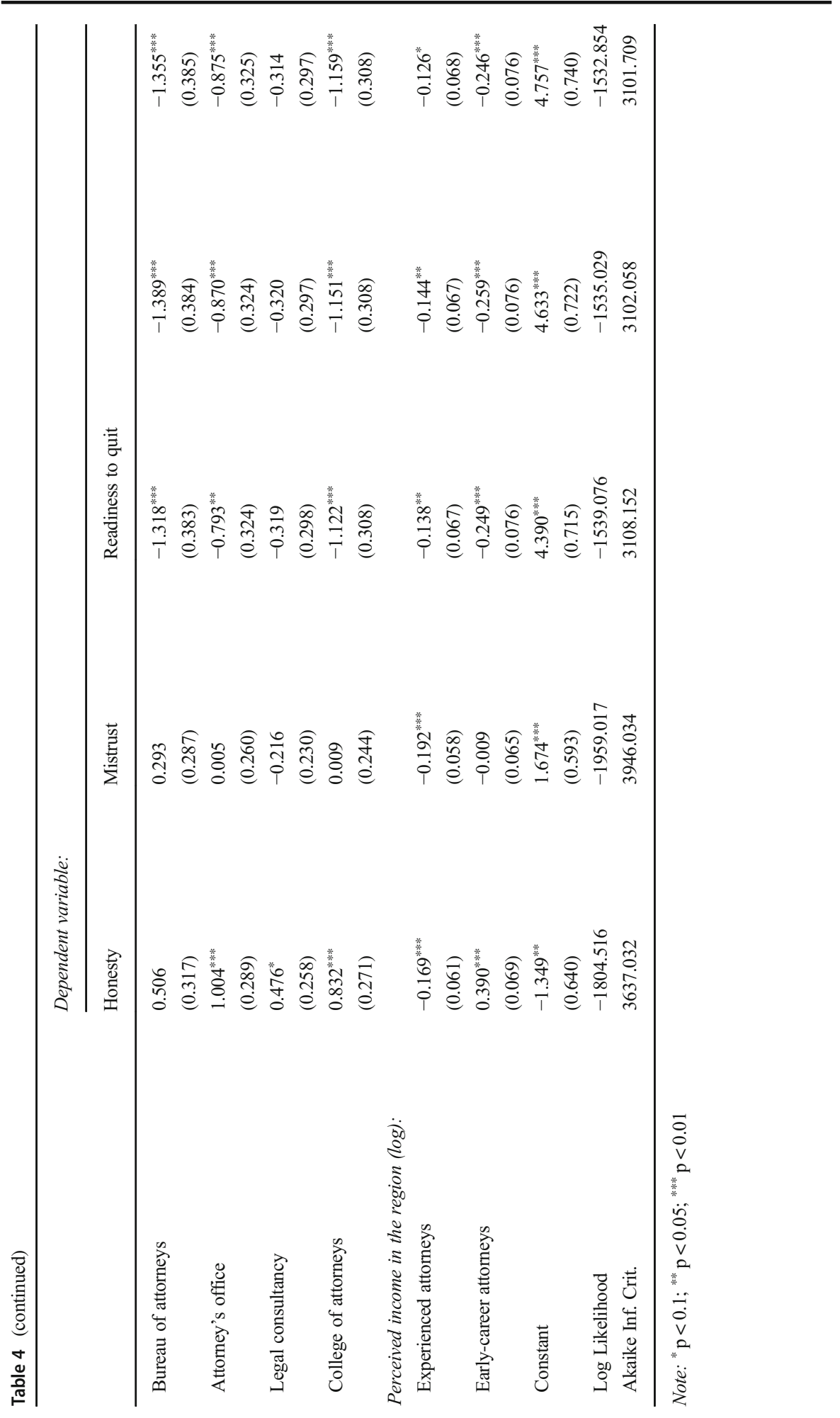


- $H_{5}$. Indicated (proclaimed) readiness to leave the profession coincides with actual departures in the following year(s).

\section{Dependent and independent variables}

To test our hypotheses, we use several dependent variables - honesty, mistrust, readiness to quit, and left voluntarily. To construct the first three variables, we have created dichotomous variables for the responses to the questions from the survey where 'absolutely disagree' and 'rather disagree' were coded as ' 0 ' and 'rather agree' and 'absolutely agree' - as ' 1 '. The last variable (left voluntarily) is constructed from the Ministry of Justice data as the proportion of attorneys who revoked their attorney status voluntarily to the total number of attorneys disbarred in 2015, which is a year following the year of the survey.

Independent variables measure the extent of the violations of the defendants' rights - as an index (violations of rights index); the proportion of disbarred attorneys due to violations of ethics (unethics2out), and the frequency of connections with the RCA (bar ties index).

Our analysis also includes a set of control variables drawn both from the regional and the individual levels. In all our models, we use individual-level variables derived from the survey - age, gender, years of working as an attorney showing the respondents' experience of working as attorneys in years, education showing whether the primary education of a respondent is a law school or not; and a group level variable measuring the proportion of attorneys to the population of a given region (attorneys per capita). Additionally, we control for the type of organisation an attorney is working for, each added as a dummy variable. In Model 6, we control for the perceived demand for legal services (demand) measured on a regional level using survey responses to the question of how the demand for attorneys' services has changed over the last five years.

Since some of our variables had many non-responses (NAs), sometimes up to $30 \%$ of the total sample, we employed multiple imputations using Amelia package in R [73] to complete the data using existing responses automatically. This process yields similar results on regression models. Summary statistics is presented in Table 5.

\section{Analysis}

To test our hypotheses, we use regression analysis on five models. Models 1 to 5 are calculated using a standard logit regression as the dependent variables (honesty, mistrust, readiness to quit) are binary, whereas to calculate Model 6 we used OLS regression.

In our first models, we model the effects of frequent violations of an attorney's clients' rights by law-enforcement on the attorney's self-legitimacy $\left(\mathrm{H}_{1}\right)$. As mentioned above, we measure self-legitimacy via respondent's beliefs that the legal profession is an example of an honest one (Model 1), and a perceived feeling of mistrust from the population (Model 2). In line with Hypothesis 1, frequent violations of clients' rights by law enforcement officers undermines self-legitimacy of attorneys. On the one hand, it decreases their belief in the honesty of the legal profession (for every one unit change in violations of rights (index) the log odds of confidence in professional integrity decreases by 0.514 ). On the other hand, it increases perceptions of mistrust in the general 
Table 5 Regression results analysis for H5. $(N=35)$

Dependent variable:

\begin{tabular}{ll}
\hline & Left voluntarily \\
Readiness to quit (2014) & $0.246^{*}$ \\
\# of attorneys to population per capita & $(0.131)$ \\
& 0.010 \\
Perceived demand for legal services (2014) & $(0.022)$ \\
& 0.076 \\
Constant & $(0.057)$ \\
R $^{2}$ & $0.549^{* * * *}$ \\
Adjusted R & $(0.049)$ \\
Residual Std. Error & 0.217 \\
F Statistic & 0.141 \\
\hline
\end{tabular}

Note: ${ }^{*} p<0.1 ;{ }^{* *} p<0.05 ;{ }^{* * *} p<0.01$

population (for every one unit change in violations of rights (index) the log odds of feelings of mistrust increase by 0.305 ).

Next, we are interested in how attorneys' self-legitimacy $\left(\mathrm{H}_{2}\right)$ and their ties with colleagues $\left(\mathrm{H}_{3}\right)$ influence their desire to quit the profession. The results for Model 3 provide empirical support for Hypothesis 2, showing that attorneys with low levels of self-legitimacy are more eager to leave the profession. In line with Hypothesis 3, Model 4 shows that attorneys with closer and more frequent interactions with their colleagues, measured via their involvement in various types of activities of the RCA, have higher levels of self-legitimacy and are less willing to leave the profession.

Keeping in mind regional heterogeneity in Russia and the self-governing nature of regional chambers, we test their effects of their role in a disbarment procedure on the attorneys' proclaimed desire to leave the profession $\left(\mathrm{H}_{4}\right)$. Model 5 is built using a regional level variable of the proportion of attorneys being disbarred due to violations of professional, and ethical conduct to the total number of attorneys being disbarred. In line with our previous models, we also include variables measuring self-legitimacy of attorneys and their connections to their colleagues as additional controls.

Model 5 shows that frequent disbarments due to violations of ethical conduct significantly lowers an attorney's readiness to quit the profession $\left(\mathrm{H}_{5}\right)$. By excluding members of the community who violate ethical standards, regional chambers sustain the desired quality of legal services. They also send important signals to two groups attorneys, who regain the belief that their profession is an honest one, and the public, who may feel more trust towards attorneys. As our main independent variable of interest (unethics2out) is a group-level variable that is the same for all respondents from a given region, we add interaction effects of this variable to the ratio of attorneys to the population in Model 5. This prevents our results from being skewed due to regions having a higher number of attorneys in total or disbarred as compared to others.

Our findings demonstrate that violations of the defendants' rights by law enforcement and control by professional associations have a direct influence on attorneys' self- 
legitimacy. Being surrounded by colleagues violating professional and ethical conduct without any real repercussions on the one hand, and frequent violations of their clients' rights by law enforcement on the other, significantly increases the attorneys' proclaimed desire to leave the profession. But, more importantly, do such intentions transform into real action?

In our final model, we test the hypothesis that proclaimed readiness to leave the profession is connected with increased numbers of voluntary departures from the profession in the following year $\left(\mathrm{H}_{5}\right)$. We do not have any panel data to track the respondents' change of attitudes and its transformation into real withdrawals from the profession. Instead, we use regional level data from the Ministry of Justice on the number of attorneys who voluntarily revoked their license in 2015 as our main dependent variable (Table 2). We calculate this variable, left voluntarily, as a ratio of a number of attorneys voluntarily revoking their licenses to a total number of attorneys who left their status, either voluntarily or as a result of disciplinary proceedings in 2015. The independent variable is constructed from responses to the survey on readiness to leave the profession, generalised to a regional level.

Our findings show that in regions where attorneys were more willing to leave the profession in 2014, there is indeed a higher outflow of attorneys in the following year (2015) (Fig. 1). These results are significant when controlling for attorneys per capita and the perceived demand for legal services generalised on a regional level. While we cannot claim the causal relationship between expressed readiness to leave the profession of an attorney and actual departures from the profession, we can prove a statistically significant relationship between them. Graph 1 plots the results of our regression model, showing a strong and positively associated relationship between our variables of interest.

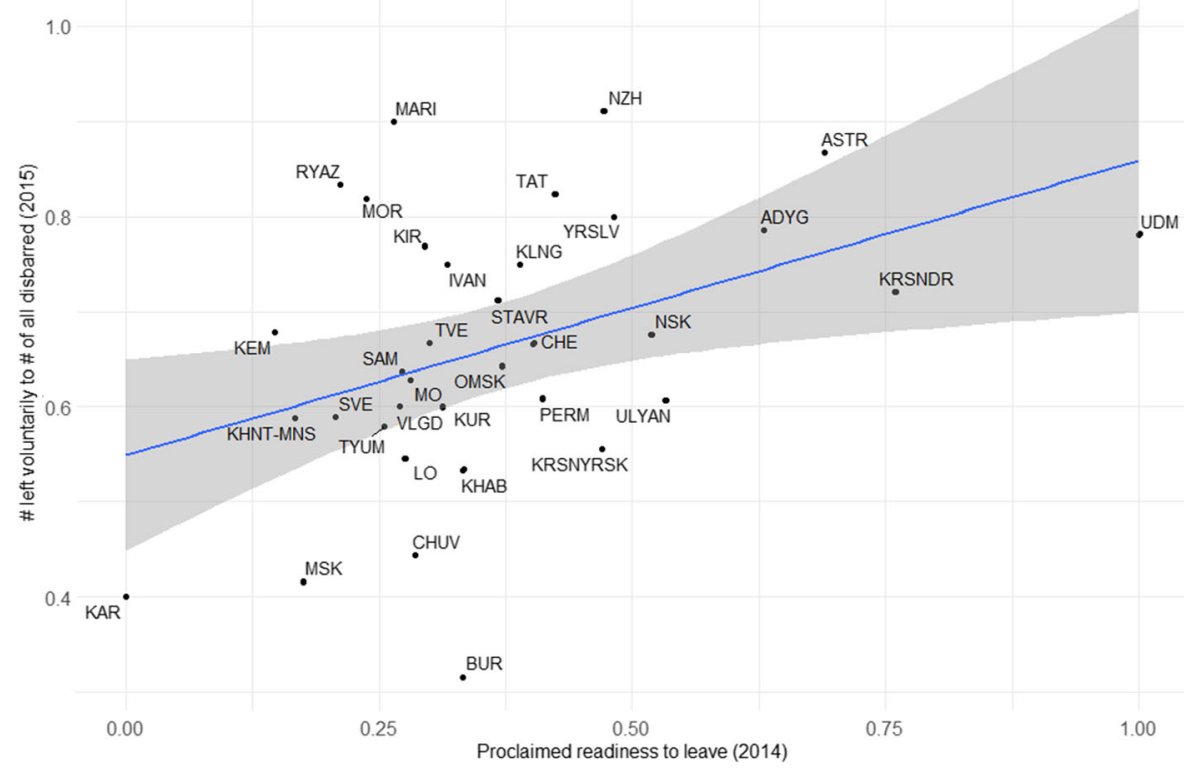

Fig. 1 Visualisation of the regression model for the ratio of attorneys left voluntarily (2015) explained by the proclaimed readiness to leave (2014) 


\section{Limitations of this study}

In this paper, we provide an analysis of self-legitimacy of attorneys working in nondemocratic countries, taking a case of Russia. Our paper has several shortcomings related to incomplete data. Our analysis is based on a survey of Russian attorneys, covering slightly less than half of the regions of the country. Other surveys on legal professionals that we are aware of include Hendley's [74] survey of the 2015 cohort of law graduates from ten regions and Baird \& Javeline's [75] survey of lawyers working outside of the criminal justice system in 12 Russian cities. However, there is no survey of attorneys in Russia, apart from the one we base our study on. Even though it would have been better to have data for all regions, it is simply impossible due to its unavailability. Nevertheless, our survey is designed as a representative survey with regions selected based on their representativeness of the whole country, and deviations in socio-demographic characteristics from the Russian Federal Bar Association do not exceed $3 \%$. Thus, we believe we base our analysis on the best available data. We also have employed an additional robustness check by weighting survey data to account for regional representation. The results are stable for both original and weighted data.

As the survey was designed as an anonymous one, it would be impossible to conduct another survey round with the same respondents. An access to such panel data would have allowed us to make more reliable conclusions about the self-legitimacy of attorneys and its influence on their desire to leave the profession. Here, once again, we have to rely on the only available source of data, publicly available aggregated statistics of the Russian Ministry of Justice, which does not allow us to consider the career trajectories of individual attorneys.

Since some of the variables used in the analysis have missing values (sometimes up to $20-30 \%$ of a total sample), we had to rely on multiple imputation techniques for missing data. Hence, we provide models used for robustness checks for H1-4 using original data with missing values, which provide similar results.

Another critical factor is that our study does not focus on other reasons why attorneys decide to leave the profession, which could be connected to income (although we partially control this factor) or personal, not related to professional activity, reasons. In some cases, attorneys may decide to revoke their license but still practice law (except for criminal cases) as private practitioners. Moreover, there is little known about lawyers working in the legal sphere without ever obtaining an attorney status. According to the report of the Institute for the Rule of Law [53], it is difficult to count the exact number of private lawyers in Russia.

However, despite these limitations, our results are still stable when checked on different types of models and variations of data. Thus, we hope that our study can serve as a first step towards explaining factors contributing to the desire to leave the attorney profession in Russia.

\section{Conclusion}

Our study shows that systemic violations of the rights of defendants by law enforcement negatively influence the self-legitimacy of attorneys, which is measured via a perceived public trust and a general belief in the honesty of the legal profession. In turn, 
this predetermines the attorneys' readiness to leave the profession, which transforms into real action with an increased number of attorneys revoking their licenses voluntarily in the following year(s). These effects, however, can be mitigated by stronger connections to colleagues in their professional associations and an active role played by the professional organisation in disbarring its members found in violation of professional behaviour.

This conclusion is crucial for our understanding of the conditions in which attorneys have to fulfil their professional duties in countries with non-democratic regimes. In non-democracies, attorneys often face various violations of theirs and their clients' rights before, during and after the trial. As a consequence, attorneys have to enter into 'fight' with representatives of the government while performing otherwise an ordinary task of legal representation. Hence, such actions could in some cases end up with collective action organised by the legal community aimed at a change of the political regime [49, 76-79].

Another possible consequence of the systemic outflow of attorneys influenced by the frequency of violations by law enforcement agencies and judges is adverse selection. From one side, we would expect the strongest and most persistent attorneys who are ready to resist the prosecution and judges when their clients' rights are violated to stay in the profession. However, in such institutional settings, honest attorneys may be more inclined to leave the profession, whereas those who do not object to the existing situation will remain. In the long term, this could increase the polarisation of the professional community and lead to an internal conflict between attorneys with contradictory values, as has been seen in other countries [8, 80]. A possible outcome of this may be an inability to organise collective action and the risk of losing the independence of the whole community [10].

Even though self-legitimacy is important for professionals regardless of the political regimes they are working in, we argue that maintaining self-legitimacy in nondemocratic regimes becomes a critical factor in preserving the independence of the legal profession. At the same time, it is essential to point out that in authoritarian states, the threat to a lawyer's legitimacy is much higher due to regular violations of the rights of defendants by judges and law enforcement officers who undermine the faith of lawyers in the significance of their work.

In this article, we have analysed only one of the most significant consequences of attorneys' loss of self-legitimacy, but it is probably not the only one. Other studies demonstrate that this could lead to a decrease in the quality of legal services or opportunistic behaviour [42, 43]. In Russia, there are 'pocket attorneys' [55] who are appointed by the state for defendants without other legal representation, and their work is mainly to benefit the state officials and not the defendant [19].

Our study contributes to the scholarship on the professional activity of attorneys. In our analysis, we apply the concept of self-legitimacy that has been predominantly used in studies on law-enforcement officers to a new professional group, i.e. attorneys. As our paper shows, self-legitimacy plays a role as important for attorneys as for lawenforcement officers. Secondly, we analyse the problem of attorneys leaving their profession in the context of imperfect institutional settings by showing how systematic violations of the rights of defendants by law enforcement can negatively impact attorneys' self-legitimacy. 
Besides, our study is the first one to our knowledge to analyse the influence of professional associations (regional chambers of attorneys) and their disciplinary procedures for violations of ethical conduct on the readiness of attorneys to stay in the profession. Active exclusion of dishonest and unethical members of the chambers, at least in part, keeps bona fide attorneys from leaving. The lack of control and punishment over the behaviour of attorneys by the professional organisation provides a bad example to other members of the group. Namely, it shows that any behaviour is tolerated and professional standards do not apply in most cases, which in turn gives rise to dishonesty and unethical behaviour. Thus, professional associations of attorneys and their willingness to punish their members for violations of ethics play an important role in sustaining the quality of services provided by the professional group.

Acknowledgements We are grateful to Andrei Yakovlev for his valuable comments on the paper, and Ekaterina Khodzhaeva, Yulia Shesternina, Ekaterina Moiseeva, and Kirill Titaev from the Institute for the Rule of Law at the European University in Saint Petersburg for preparing survey instruments and polling attorneys. This project would have been impossible without the organisational support of the Federal Chamber of Lawyers, represented by its President Yuri Pilipenko, Anastasia Potapova and Alexander Krokhmalyuk, and the heads of the regional chambers of advocates. We are also grateful to all the attorneys who took part in our survey. We would like to thank the participants of the colloquium of the Research Centre for East European Studies at the University of Bremen and the Development of Russian Law Conference 2018 in Helsinki, Lauren McCarthy and two anonymous reviewers for their comments. All mistakes and errors are entirely our own.

Availability of data and material Data used in this article is available upon request.

Funding This work was supported within the framework of the Basic Research Program at the National Research University Higher School of Economics (HSE) and by the Russian Academic Excellence Project '5100'. Yulia Khalikova received funding from the European Union's Horizon 2020 research and innovation programme under the Marie Skłodowska-Curie grant agreement No 713639.

\section{Compliance with ethical standards}

Conflict of interests The authors declare that they have no conflict of interest.

Code availability Data was collected and analysed using SPSS and RStudio software, replication code for recoding of variables, and empirical analysis is available upon request.

Open Access This article is licensed under a Creative Commons Attribution 4.0 International License, which permits use, sharing, adaptation, distribution and reproduction in any medium or format, as long as you give appropriate credit to the original author(s) and the source, provide a link to the Creative Commons licence, and indicate if changes were made. The images or other third party material in this article are included in the article's Creative Commons licence, unless indicated otherwise in a credit line to the material. If material is not included in the article's Creative Commons licence and your intended use is not permitted by statutory regulation or exceeds the permitted use, you will need to obtain permission directly from the copyright holder. To view a copy of this licence, visit http://creativecommons.org/licenses/by/4.0/.

\section{References}

1. Parker, C., \& Evans, A. (2007). Inside Lawyers' ethics. Cambridge: Cambridge University Press.

2. Rhode, D, L. (2003). Ethics in practice: Lawyers' roles, responsibilities, and regulation. Oxford University Press. 
3. Silver, M. (2006). The professional responsibility of lawyers: Emotional competence, multiculturalism and ethics. Journal of Law and Medicine, 13(4), 431-438.

4. Evetts, J. (2003). The sociological analysis of professionalism occupational change in the modern world. International Sociology, 18(2), 395-415.

5. Moustafa, T. (2014). Law and courts in authoritarian regimes. Annual Review of Law and Social Science, 10, 281-299.

6. Ahmed, Z., \& Stephan, M. (2010). Fighting for the rule of law: Civil resistance and the Lawyers' movement in Pakistan. Democratization, 17(3), 492-513.

7. Boukalas, C. (2013). Politics as legal action/lawyers as political actors towards a reconceptualisation of cause lawyering. Social \& Legal Studies, 22(3), 395-420.

8. Gobe, E., \& Salaymeh, L. (2016). Tunisia's 'Revolutionary' lawyers: From professional autonomy to political mobilization. Law \& Social Inquiry, 41(2), 311-345.

9. Hendley, K. (2020). Assessing the potential for renegades among Russian millennial lawyers. Demokratizatsiya, 28(1), 43-175.

10. Kazun, A., \& Yakovlev, A. (2019). Legal mobilization in Russia: How organizations of lawyers can support social changes. Crime, Law and Social Change, 72(3), 303-325.

11. Levitsky, S., \& Way, L. A. (2010). Competitive authoritarianism: Hybrid regimes after the cold war. New York: Cambridge University Press.

12. Sakwa, R. (2010a). The dual state in Russia. Post-Soviet Affairs, 26(3), 185-206.

13. Sakwa, R. (2010b). The crisis of Russian democracy: The dual state. Factionalism and the Medvedev Succession: Cambridge University Press.

14. Hendley, K. (2007). Are Russian judges still soviet? Post-Soviet Affairs, 23(3), 240-274.

15. Hendley, K. (2015). Resisting multiple narratives of law in transition countries: Russia and beyond. Law \& Social Inquiry, 40(2), 531-552.

16. Volkov, V. (2004). Hostile Enterprise takeovers: Russia's economy in 1998-2002. Review of Central and East European Law, 29(4), 527-548.

17. Frye, T. (2017). Property rights and property wrongs: How power, Institutions and Norm Shape Economic Conflict in Russia. Cambridge: Cambridge University Press. doi:https://doi.org/10.1017/ 9781316661727.

18. Paneyakh, E. (2014). Faking performance together: Systems of Performance Evaluation in Russian enforcement agencies and production of Bias and privilege. Post-Soviet Affairs, 30(2-3), 115-136.

19. Moiseeva, E. (2017). Plea bargaining in Russia: The role of defense attorneys and the problem of asymmetry. International Journal of Comparative and Applied Criminal Justice, 41(3), 163-184.

20. Kazun, A. (2015). Violent corporate raiding in Russia: Preconditions and protective factors. Demokratizatsiya: The Journal of Post-Soviet Democratization, 23(4), 459-484.

21. Taylor, B. (2014). Police reform in Russia: The policy process in a hybrid regime. Post-Soviet Affairs, 30(2-3), 226-255.

22. Golosov, G. (2011). The regional roots of electoral authoritarianism in Russia. Europe-Asia studies, 63(4), 623-639. https://doi.org/10.1080/09668136.2011.566427.

23. Limonov, L., \& Nesena, M. (2016). Regional cultural diversity in Russia: Does it matter for regional economic performance? Area development and policy, 1(1), 63-93. https://doi.org/10.1080/23792949. 2016.1164016.

24. Sidorkin, O., \& Vorobyev, D. (2017). Political cycles and corruption in Russian regions. European Journal of Political Economy, 52, 55-74.

25. Chambers, D. (2013). Overstating the satisfaction of lawyers. Law \& Social Inquiry, 39(2), 313-333.

26. Dinovitzer, R., \& Garth, B. (2007). Lawyer satisfaction in the process of structuring legal careers. Law \& Society Review, 41(1), 1-50.

27. Brockman, J. (1994). Leaving the practice of law: The wherefores and the whys. Alberta Law Review, 32(1), 116-180.

28. Kay, F. (1997). Flight from law: A competing risks model of departures from law firms. Law \& Society Review, 31(2), 301-336.

29. Markovic, M., \& Gabriele Plickert, G. (2018). Attorneys' career dissatisfaction in the new Normal. International Journal of the Legal Profession, 25(2), 147-173.

30. Kay, F., \& Hagan, J. (2003). Building trust: Social capital, distributive justice, and loyalty to the firm. Law \& Social Inquiry, 28(2), 483-519.

31. Wallace, J. (2001). The benefits of mentoring for female lawyers. Journal of Vocational Behavior, 58(3), 366-391.

32. Hagan, J., \& Kay, F. (2007). Even lawyers get the blues: Gender, depression, and job satisfaction in legal practice. Law \& Society Review, 41(1), 51-78. 
33. Roach Anleu, S., \& Mack, K. (2014). Job satisfaction in the judiciary. Work, Employment and Society, 28(5), 683-701.

34. Zheng, C., Jiahui, A., \& Liu, S. (2017). The elastic ceiling: Gender and professional career in Chinese courts. Law \& Society Review, 51(1), 168-199.

35. Hagan, J., \& Kay, F. (1995). Gender in practice: A study of Lawyers' lives. New York: Oxford University Press.

36. Kay, F., Alarie, S., \& Adjei, J. (2014). Leaving law and barriers to re-entry: A study of departures from and re-entries to private practice. Law Society of Upper Canada. https://www.deslibris.ca/ID/240126

37. Yoon, A. (2017). Legal profession and the market for lawyers. The Oxford handbook of law and economics: Volume 3: Public law and legal institutions, 259.

38. Meško, G., Hacin, R., Tankebe, J., \& Fields, C. (2017). Self-legitimacy, Organisational commitment and commitment to fair treatment of prisoners: An empirical study of prison officers in Slovenia. European Journal of Crime, Criminal Law and Criminal Justice, 25(1), 11-30.

39. Tankebe, J. (2019). In their own eyes: An empirical examination of police self-legitimacy. International journal of comparative and applied criminal justice, 43(2), 99-116. https://doi.org/10.1080/01924036. 2018.1487870.

40. Bottoms, A., \& Tankebe, J. (2012). Beyond procedural justice: A dialogic approach to legitimacy in criminal justice. Journal of Criminal Law and Criminology, 102(1), 119-170.

41. Raaijmakers, E., De Keijser, J., Nieuwbeerta, P., \& Dirkzwager, A. (2015). Criminal Defendants' satisfaction with lawyers: Perceptions of procedural fairness and effort of the lawyer. Psychology, crime \& law, 21(2), 186-201. https://doi.org/10.1080/1068316X.2014.951646.

42. Bradford, B., \& Quinton, P. (2014). Self-legitimacy, police culture and support for democratic policing in an English constabulary. British Journal of Criminology., 54(6), 1023-1046.

43. Nix, J., \& Wolfe, S. (2017). The impact of negative publicity on police self-legitimacy. Justice Quarterly, 34(1), 84-108.

44. Noppe, J. (2018). Are all police officers equally triggered? A test of the interaction between moral support for the use of force and exposure to provocation. Policing and Society, 28, 605-618.

45. Prenzler, T., Porter, L., \& Alpert, G. (2013). Reducing police use of force: Case studies and prospects. Aggression and Violent Behavior, 18, 343-356.

46. Liang, B., Phil He, N., \& Lu, H. (2014). The deep divide in China's criminal justice system: Contrasting perceptions of lawyers and the Iron triangle. Crime, Law and Social Change, 62, 585-601.

47. Michelson, E. (2007). Lawyers, political Embeddedness, and institutional continuity in China's transition from socialism. American Journal of Sociology, 113(2), 352-414.

48. Halliday, T. \& Karpik, L. (1997). Lawyers and the rise of Western political liberalism: Europe and North America from the eighteenth to twentieth centuries. Oxford University Press on Demand.

49. Munger, F. W., Cummings, S. L., \& Trubek, L. G. (2013). Mobilizing law for justice in Asia: A comparative approach. Wisconsin International Law Journal, 31, 353-420.

50. Butler, W. (2011). The Russian legal practitioner. The Hague: Eleven International Publishing.

51. Kazun, A., \& Yakovlev, A. (2017). Who demands collective action in an imperfect institutional environment? A case study of the profession of advocates in Russia. Journal of Eurasian Studies, $8(1), 60-71$.

52. Maggs, P, B., Schwartz, O., \& Burnham, W. (2015). Law and legal system of the Russian Federation. New York: Juris Publishing, Inc.

53. Moiseeva, E., \& Skugarevsky, D. (2016). The market for legal services: What does statistics say. Analytical report [Rynok Yuridicheskikh Uslug v Rossii: Chto Govorit Statistika. Analyticheskii Obzor]. St.Petersburg: IPP EU SPb.

54. Avilov, A. (2018). Russian Courts Acquit $0.3 \%$ of People at Trials in 2017. The Moscow Times. https:// themoscowtimes.com/news/russian-courts-acquit-03-people-trials-2017-60592.

55. Khodzhaeva, E., \& Rabovski, J. (2015). Strategies and tactics of criminal defenders in the context of «accusatorial Bias» («obvinitelinyi uklon») in Russia. Sociology of Power, 27, 135-167.

56. Paneyakh, E. (2016). The practical logic of judicial decision making. Russian Politics \& Law, 54(2-3), 138-163.

57. Volkov, V. (2012). How judges pass decisions: Empirical legal studies. Moscow: Statut.

58. McCarthy, L. A. (2015). Trafficking justice: How Russian police enforce new Laws, from crime to courtroom. Ithaca, NY: Cornell University Press.

59. Paneyakh, E. (2008). The rules of the game for a Russian businessman. Moscow: KoLibri.

60. Paneyakh, E. (2012). Law enforcement in Russia: Structure, functioning, ways of reforming [Pravookhranitel' naya Deyatel' nost' v Rossii: Struktura, Funktsionirovanie, Puti Reformirovaniya]. St.Petersburg: IPP EU SPb. 
61. Titaev, K., \& Shkliaruk, M. (2016). Investigators in Russia. Russian Politics \& Law, 54(2-3), $112-137$.

62. Kaminskaya, D. (2009). Attorney's Diaries [Zapiski Advokata]. Moscow: Novoe Izdatel' stvo.

63. Stern, R. (2017). Activist lawyers in post-Tiananmen China. Law \& Social Inquiry, 42(1), 234-251.

64. Chua, L. (2014). Mobilizing gay Singapore: Rights and resistance in an authoritarian state. Philadelphia: Temple University Press.

65. Levin, L., \& Mather, L. (Eds.) (2012). Lawyers in practice: Ethical decision making in context. Chicago: University of Chicago Press.

66. Akoensi, T. (2016). Perceptions of self-legitimacy and audience legitimacy among prison officers in Ghana. International Journal of Comparative and Applied Criminal Justice, 40(3), 245-261.

67. Hacin, R., Fields, C., \& Mesko, G. (2019). The self-legitimacy of prison staff in Slovenia. European Journal of Criminology, 16(1), 41-59.

68. Doornbos, N., \& De Groot-van Leeuwen, L. (2012). Incorrigible advocates. Legal Ethics, 15(2), 335355.

69. Levin, L. (2012). Misbehaving lawyers: Cross-country comparisons. Legal Ethics, 15(2), 357-377.

70. Regan, M. C. (2004). Eat what you kill: The fall of a wall street lawyer. Ann Arbor: University of Michigan Press.

71. Abel, R. (1991). American lawyers. New York: Oxford University Press.

72. Abel, R. (2012). Comparative studies of lawyer deviance and discipline. Legal Ethics, 15(2), 187-195.

73. Honaker, J., King, G., \& Blackwell, M. (2011). Amelia II: A program for missing data. Journal of Statistical Software, 45(7), 1-47.

74. Hendley, K. (2016). Evaluating the prospects for young lawyers to remake Putin's Russia. Russian Politics, 1(4), 450-477.

75. Baird, V., \& Javeline, D. (2010). The effects of national and local funding on judicial performance: Perceptions of Russia's lawyers. Law \& Society Review, 44(2), 331-364.

76. Berg, M., \& Rogers, E. (2017). The mobilization of criminal law. Annual Review of Law and Social Science, 13, 451-469.

77. Boutcher, S. (2011). Rethinking culture: Organized pro bono and the external origins of culture. University of St. Thomas Law Journal, 8(2), 108-128.

78. Karpik, L., \& Halliday, T. (2011). The legal complex. Annual Review of Law and Social Science, 7, 217236.

79. Kawar, L. (2011). Legal mobilization on the terrain of the state: Creating a field of immigrant rights lawyering in France and the United States. Law \& Social Inquiry, 36(2), 354-387.

80. Winn, J., \& Yeh, T. (1995). Advocating democracy: The role of lawyers in Taiwan's political transformation. Law \& Social Inquiry, 20(2), 561-599.

Publisher's note Springer Nature remains neutral with regard to jurisdictional claims in published maps and institutional affiliations. 